Boletín de la Sociedad Geológica Mexicana

VOLUMEN 61, NÚM. 2, 2009, P. 203-209

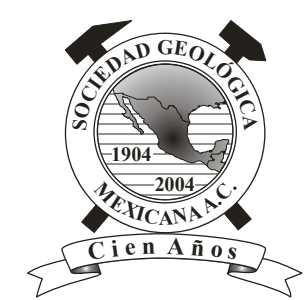

\title{
First described species of Costacopluma (Crustacea: Brachyura: Retroplumidae) from the Pacific slope, Paleocene of California, USA
}

\author{
Torrey Nyborg ${ }^{1, *}$, Francisco J. Vega ${ }^{2}$, Harry F. Filkorn ${ }^{3}$ \\ ${ }^{1}$ Department of Earth and Biological Sciences, Loma Linda University, Loma Linda, CA 92350. \\ ${ }^{2}$ Instituto de Geología, UNAM, Ciudad Universitaria, Coyoacán, México DF 04510, Mexico. \\ ${ }^{3}$ Department of Invertebrate Paleontology, Natural History Museum of Los Angeles County, 900 Exposition Boulevard, Los Angeles, \\ CA 90007.
}

*tnyborg06g@1lu.edu

\begin{abstract}
A new species of the brachyuran crab Costacopluma Collins and Morris, 1975, Costacopluma squiresi, is described from lower Paleocene strata of the San Francisquito Formation and upper Paleocene strata of the Santa Susana Formation of southern California. Costacopluma squiresi represents the first described species of Costacopluma from the Pacific Coast of North America.
\end{abstract}

Keywords: Crustacea, Costacopluma, Paleocene, California.

\section{Resumen}

Una especie nueva de cangrejo braquiuro Costacopluma Collins y Morris, Costacopluma squiresi, es descrita de estratos del Paleoceno Inferior de la Formación San Francisquito y de estratos del Paleoceno Superior de la Formación Santa Susana del sur de California. Esta especie representa la primera especie descrita de Costacopluma en la costa del Pacifico de Norteamérica.

Palabras clave: Crustacea, Costacopluma, Paleoceno, California. 


\section{Introduction}

Two specimens of Costacopluma have been discovered in outcrops of Paleocene strata of the San Francisquito and Santa Susana formations of southern California. One of these specimens was reported earlier, but the species was not described or named (Nyborg et al., 2003). One of the specimens was collected from an outcrop of the lower Paleocene (Danian) portion of the lower San Francisquito Formation northwest of Warm Springs Mountain, Los Angeles County, California (Figure 1, LACMIP locality 21580), which is part of a small area of outcrop in the central Transverse Ranges (Kirby and Saul, 1995; Prothero and Vacca, 2001). The San Francisquito Formation ranges in age from latest Cretaceous to late Paleocene (Dibblee, 1967; Sage, 1973; Kooser, 1980, 1982; Kirby and Saul, 1995; Squires, 1997; Prothero and Vacca, 2001) and consists of $100 \mathrm{~m}$ of shallow-marine deposits overlain by and interfingering with deep marine sediments (Sage, 1973; Kirby, 1991). In the vicinity of Warm Springs Mountain, the San Francisquito Formation is part of a shallow-marine phase of a transgressive sequence that continued across the Cretaceous/Tertiary boundary and into the Paleocene (Kooser, 1980; Kirby, 1991; Kirby and Saul, 1995). The horizon containing the Cretaceous/Tertiary boundary near Warm Springs Mountain is within an $8 \mathrm{~m}$-thick interval composed of shoreface, transition zone and offshore deposits (Kirby, 1991). Deposition of the basal portion of the San Francisquito Formation was probably nearly continuous across the Cretaceous/Tertiary boundary based on sedimentology (Kirby, 1991), as well as on biostratigraphic age constraints primarily recognized by the Turritella zonation of Saul (1983b). Abundant specimens of the gastropod Turritella peninsularis quaylei Saul, 1983, a taxon which indicates the horizon is within the Danian Stage of the Paleocene Series, and the specimen of Costacopluma squiresi were collected from beds approximately $75 \mathrm{~m}$ above the Cretaceous/Tertiary boundary (Kirby, 1991; Kirby and Saul, 1995).

The second specimen was collected from shallowmarine beds in the upper portion of the Santa Susana Formation in Quarry Canyon, in the east-central Santa Monica Mountains, Los Angeles County, California (Figure 1, LACMIP locality 11688; see Squires and Saul, 1998 and 2007 , for details of the stratigraphy in this area). A recent geologic map of the region (Dibblee, 1992) and subsequent stratigraphic and paleontologic investigations (Colburn, 1996; Colburn et al., 1988; Squires and Kennedy, 1998; Squires and Saul, 1998) have demonstrated that the rocks in Quarry Canyon are part of the Santa Susana Formation. The lithology of the outcrop from which the specimen was collected consists of coralline-algal-rich muddy siltstone that is related to adjacent beds of coralline-algal limestone and interpreted to have been deposited in nearshore, tropical to subtropical conditions (Squires and Saul, 2007). Squires and Saul (1998) assigned the strata of Quarry Canyon and the surrounding area to the provincial "Martinez Stage" of late Paleocene age. Colburn et al. (1988) and Colburn

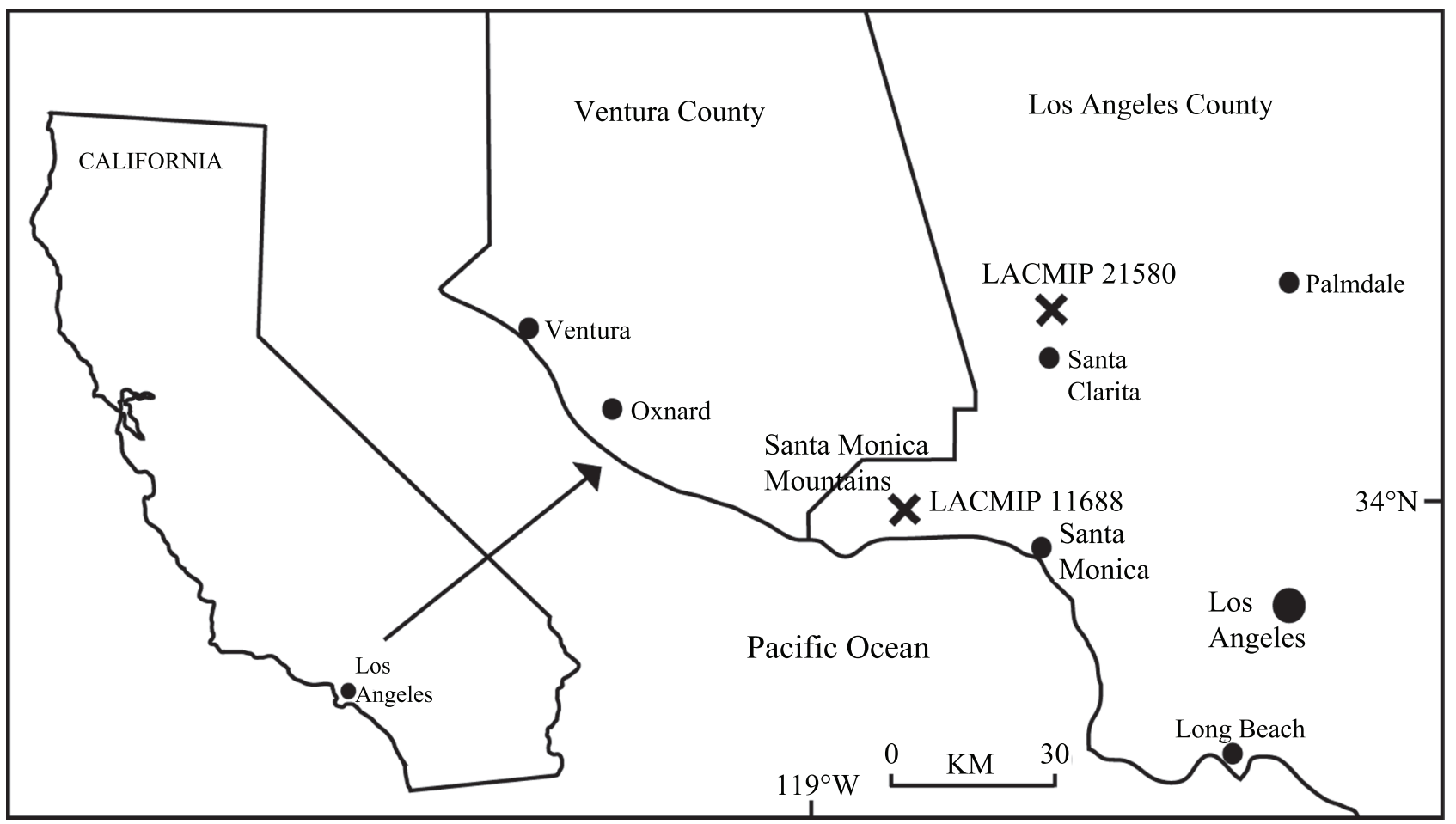

Figure 1. Generalized location map showing position of the two localities where Costacopluma squiresi new species, was collected. 
(1996) concluded that the upper portion of the Santa Susana Formation was deposited in a low-energy protected bay that was not more than $40 \mathrm{~m}$ in depth. Macrofossils and microfossils collected from outcrops of the Santa Susana Formation in the Santa Monica Mountains (Squires, 1997; Squires and Saul, 1998; Squires and Kennedy, 1998) and in the Simi Hills (Zinsmeister, 1983a, 1983b; Saul, 1983a, 1983b; Heitman, 1983; Frederickson, 1983; Filewicz and Hill, 1983; Squires, 1999) are indicative of a late Paleocene age. Two other fossil crabs have been reported previously from the Santa Susana Formation: Cyclocorystes aldersoni Squires, 1980, and Zanthopsis sp. aff. Z. hendersoni Rathbun, 1926 (Squires, 1999).

\section{Systematic Paleontology}

Infraorder Brachyura Latreille, 1802

Section Eubrachyura Saint-Laurent, 1980

Subsection Heterotremata Guinot, 1977

Superfamily Retroplumoidea Gill, 1894

Family Retroplumidae Gill, 1894

Genus Costacopluma Collins and Morris, 1975

Type species. Costacopluma concava Collins and Morris, 1975, p. 823, pl. 97, figs. 1-9, by original designation.

\section{Costacopluma squiresi new species}

Figure 2.1-2.4

Costacopluma n. sp. Nyborg, Vega, and Filkorn, 2003, p. 166.

Diagnosis. Carapace small, subtrapezoidal to subhexagonal elongated, widest at posterior fourth of carapace; marginal notch separates anterolateral from lateral margins; transverse ridges moderately strong, with sharp, granulated crests; areas between ridges ornamented with very fine granules; sternum wide; male abdomen triangular; right cheliped massive.

Description. Carapace small, subtrapezoidal to subhexagonal elongated, maximum length equal to maximum width, widest at posterior fourth of carapace, three moderately strong transverse ridges with fine granulated crests mark carapace regions; regions between ridges ornamented with fine granules; anterior margin sinuous, four-fifths maximum carapace width; strong outer orbital spine; anterolateral margin slightly concave, one-fourth maximum carapace length, marginal notch at level of epibranchial region; posterolateral margin slightly inclined outward, about three-fourths maximum carapace length; posterolateral margin inclined posteriorly, slightly curved, one-fourth maximum carapace width; posterior margin straight, two-thirds maximum carapace width; anterior ridge arched, uniform in width, with sharp crest covered with fine granules; mesogastric lobe rhomboid; mid-ridge subparallel to anterior ridge, uniform in width, inclined 45 degrees with respect to posterior margin, includes epibranchial and mesobranchial lobes; posterior ridge subparallel to posterior margin, wider at junction with posterolateral margin, includes metabranchial lobes; cardiac lobe subtrapezoidal, one-third carapace width, with fused posterior lobe; intestinal region depressed; cervical groove deeply impressed around cardiac lobe.

Sternum wide, abdominal cavity deep; sternites 1 and 2 unknown; sternite 3 transversely elongated with two lateral, elongated bosses with crests covered by granules, separated from sternite 4 by deep transverse groove; sternite 4 trapezoidal, lateral margins rimmed with numerous tubercles, lateral process triangular, sharp; sternite 5 rectangular, with median ridge with coarse granules on crest, extending to triangular, sharp lateral process; sternite 6 similar to sternite 5 ; sternite 7 two-thirds width of sternite 6 , but with median, granulated crest; male abdomen triangular, elongated, all abdominal segments with a median granulated transverse crest; telson not preserved, but inferred to be triangular based on shape of sternal cavity; segment 4 subtrapezoidal; segment 3 subrectangular, one-third wider than segment 4 , but equal in length; segment 2 rectangular, one-third wider than segment 3 and slightly shorter.

Right cheliped robust; merus rectangular, length equal to one-third carapace length, height approximately half its own length, cuticle not preserved, carpus as high as merus and half its length; palm subtrapezoidal, as long as merus, wider at distal portion; dactyl not preserved, but inferred to be unciform based on impression (external mold) in concretion.

Etymology. The species name honors Richard L. Squires, prominent paleontologist and prolific publisher on the stratigraphy and paleontology of the Pacific slope of North America.

Material examined. Two specimens deposited in the collections of the Department of Invertebrate Paleontology, Natural History Museum of Los Angeles County (LACMIP). Holotype, LACMIP specimen 13560, from LACMIP locality 11688 , preserves the dorsal carapace and right cheliped. Paratype, LACMIP specimen 13561, from LACMIP locality 21580, preserves the dorsal carapace and portions of the sternum.

Measurements (in mm). Holotype, carapace length $=$ 11.2 , width $=11.5$; paratype, carapace length $=$ about 13.0, width $=15.8$.

Occurrence. The paratype, LACMIP specimen 13561, is from LACMIP locality 21580, lower Paleocene (Danian), San Francisquito Formation, about $3.5 \mathrm{~km}$ northwest of Warm Springs Mountain, south side of the East Fork of Fish Canyon, in the canyon wall about 30 feet above the stream bed, Los Angeles County, California. USGS Warm Springs 


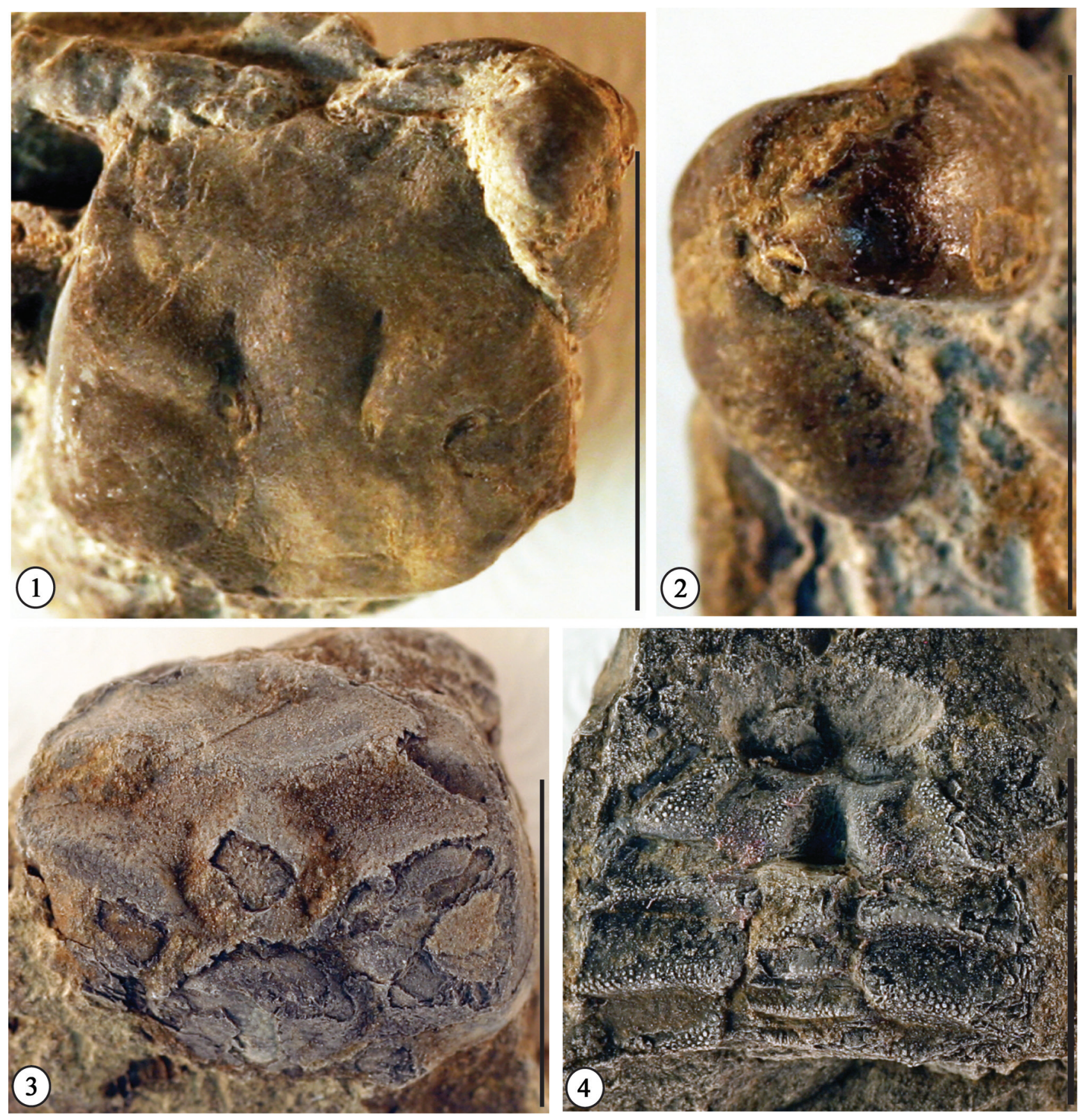

Figure 2.1 - 4. Costacopluma squiresi, new species. 1. Dorsal view of carapace, holotype LACMIP specimen 13560, Paleocene, LACMIP locality 11688. 2. Dorsal view of carapace, paratype LACMIP specimen 13561, Paleocene, LACMIP locality 21580. 3. Lateral view of right cheliped, holotype LACMIP specimen 13560. 4. Ventral view of carapace, paratype LACMIP specimen 13561. Scale bars $=1 \mathrm{~cm}$

Mountain 7.5' Quadrangle, latitude N 34 36'39', longitude W $118^{\circ} 36^{\prime} 44^{\prime \prime}$. Collected by R.W. Webb and E.H. Quayle, June 5,1941 . The holotype, LACMIP specimen 13560 , is from LACMIP locality 11688, upper Paleocene provincial "Martinez Stage", in the upper portion of the Santa Susana Formation, Quarry Canyon, near the head of Quarry Canyon and in the canyon bottom at about 1400 feet elevation, in a siltstone about 50 feet above a conglomerate, east-central Santa Monica Mountains, Los Angeles County, California.
USGS Topanga 7.5' Quadrangle, latitude N 34 5' 20", longitude W $118^{\circ} 33^{\prime} 16^{\prime \prime}$. Collected by J. M. Alderson, January, 1980.

\section{Discussion}

Costacopluma squiresi, new species, differs from all other species of the genus in having a nearly square 
carapace, weaker transverse ridges, and a dorsal surface covered by very fine granules. All the Paleogene species that have been described previously have a similar small size, but the shapes of their carapaces are distinctly different. Costacopluma senegalensis (Gorodiski and Rémy, 1959); $C$. binodosa Collins and Rasmussen, 1992; C. bifida Collins, Higgs and Cortitula, 1994; C. australis Feldmann, Casadío, Chirino-Gálvez and Aguirre-Urreta, 1995; C. nordestiana Feldmann and Martins-Neto, 1995; C. salamanca Feldmann, Rodríguez, Marínez and Aguirre-Urreta, 1997, and C. grayi Feldmann and Portell, 2007, all possess a subhexagonal to ovate carapace, stronger transverse ridges of unequal width, and relatively stronger granules on the ridge crests. A new species from the Paleocene of Texas (Armstrong et al., in press) is different from C. squiresi in having a carapace wider on the posterior third of the carapace, a notch on the anterolateral margin, shorter outer orbital spines, transverse ridges with more rounded crests ornamented with stronger tubercles, and a more swollen mesobranchial ridge.

The oldest known Costacopluma species is C. bishopi Vega and Feldmann, 1992, from the Coniacian of Guerrero, southern Mexico (Vega and Feldmann, 1992; Fraaije et al., 2006). The youngest representative is C. grayi from the Eocene of Alabama (Feldmann and Portell, 2007). During the Late Cretaceous (Campanian-Maastrichtian), Costacopluma was distributed in western Africa and north of India (Collins and Morris, 1974; Gaetani et al., 1983), northern Mexico (Vega and Perrilliat, 1989; Vega et al., 1995), southeastern United States (A. Armstrong, pers. comm.) and Colombia (J. Luque, pers. comm.). By Paleocene time, the genus showed a wider distribution, including east Africa (Gorodiski and Rémy, 1959), Greenland (Collins and Rasmussen, 1992), Texas (Armstrong et al., in press), Venezuela (Collins et al., 1994), Brazil (Feldmann and Martins-Neto, 1995; Araujo-Távora and Cruz-Miranda, 2004) and Argentina (Feldmann et al., 1995; 1997). The youngest occurrence for the genus is in Eocene sediments of Alabama (Feldmann and Portell, 2007). The presence of Costacopluma squiresi new species in the Paleocene of California is especially interesting because all previously known Cretaceous and Paleogene species of this genus occur in the Atlantic, along the ancient east coast of the Americas (from Greenland to Argentina) and the west coast of Africa. McLay (2006) suggested that $C$. mexicana, C. bishopi, C. binodosa and $C$. australis should be removed from the Retroplumidae and reassigned to the Palicidae Bouvier, 1898, based on the lack of diagnostic features for that family established by Saint-Laurent (1989), such as size proportions of the carapace (width greater than length) and the presence of transverse sternal cariane, among others. Costacopluma bishopi and $C$. mexicana have an ovate carapace with width greater than length and, in particular, C. mexicana also has strong transverse sternal carinae (Vega and Perrilliat, 1989, p. 85 , figs. $2 \mathrm{~h}$ and $2 \mathrm{j}$ ). Detailed review of the Palicidae by Castro (2000) indicated that palicids have a rough dorsal carapace surface, very small chelae, anterolateral spines and a spiny anterior. None of the species suggested by McLay (2006) to be removed from the Retroplumidae include these features. It is true that knowledge of morphological details of every species of Costacopluma is incomplete, but they all share common features that indicate they are closely related and therefore belong to the same family. Based on the general shape of the carapace, it is possible to subdivide the species of Costacopluma into two main groups: 1) the ovate carapace group, represented by the Cretaceous American and African species and the Eocene $C$. grayi, and 2) the subhexagonal carapace group, represented by Paleocene species from Greenland, Texas and South America. The quadrate carapace shape of Costacopluma squiresi suggests it belongs to group 2), and its presence in the Paleocene of California can be explained by two possible migration routes: 1) from southeastern North America, westward through the southern edge of North America (see Vega et al., 2007; 2008), or 2) from South America, northward along the east coast and then to the northwest through the southern portion of Mexico. Dispersal routes proposed for the Paleocene by Feldmann and Schweitzer (2006, fig. 2.2) support route option number 2. However, some decapod genera typically from the Paleogene West Coast have been found, along with genera from Texas and Alabama, in lower Eocene deposits of Chiapas (Vega et $a l ., 2008)$, as well as some typical Tethyan genera such as Lophoranina, that dispersed westward to inhabit the Eocene seas of Baja California (Squires and Demetrion, 1992). There is also the possibility that both routes affected the composition of Paleocene decapods assemblages along the West Coast of North America. Gardner and Bowles (1934) and Maldonado-Koerdell (1950) suggested the existence of a portal of communication between the Atlantic and Pacific oceans during early Eocene time, located in the Isthmus of Tehuantepec region. The occurrences of common decapod crustacean species in Eocene deposits of central Chiapas and Baja California (Vega et al., 2008) suggest that this oceanographic connection was probably situated near that isthmus.

\section{Acknowledgments}

We thank Richard L. Squires for bringing these decapod specimens to the attention of the authors and Steve Hetrick for his help in preparing the holotype specimen. Critical reviews of the original manuscript by G. Bishop, R. Portell, and R. Squires helped to improve this report.

\section{References}

Araújo-Távora, V. de, Cruz-Miranda, M.C. de, 2004, Sistemática e tafonomia de uma fáunula de crustáceos decápodes da Formação Maria Farinha (Paleoceno), Estado de Pernambuco, Brasil: Revista Brasileira de Paleontologia, 7, 45-52. 
Armstrong, A., Nyborg, T., Bishop, G.A., Ossó-Morales, À., Vega, F.J., In press, Decapod crustaceans from the Paleocene of central Texas, USA: Revista Mexicana de Ciencias Geológicas.

Bouvier, E.L., 1898, Observations on the crabs of the family Dorippidae: Annals and Magazine of Natural History, Series 7(1), 103-105.

Castro, P., 2000, Crustacea Decapoda: A revision of the Indo-West Pacific species of palicid crabs (Brachyura: Palicidae), in Crosnier, A. (ed.), Résultats des Campagnes MUSORSTOM 21: Mémoire du Muséum national Histoire naturelle, 184, 437-610.

Colburn, I.P., 1996, Stratigraphy and sedimentary structures of the Paleogene successions in the west central Santa Monica Mountains, Los Angeles County, California, in Abbott, P.L. (ed.), Field Conference Guidebook and Volume for the American Association of Petroleum Geologists Annual Convention, San Diego, California. Pacific Sections: American Association of Petroleum Geologists and Society for Sedimentary Geology (SEPM), Bakersfield, California, 93-116.

Colburn, I.P., Jakobsen, C.M., Novak, G.A., 1988, The Paleocene stratigraphy of the Santa Monica Mountains, Los Angeles County, California, in Filewicz, M.V., Squires, R.L. (eds.), Paleogene Stratigraphy, West Coast of North America. Pacific Section Society of Economic Paleontologists and Mineralogists: West Coast Paleogene Symposium, 58, Los Angeles, California, 59-72.

Collins, J.S.H., Morris, S.F., 1975, A new crab, Costacopluma concava, from the Upper Cretaceous of Niger: Palaeontology, 18, 823-829.

Collins, J.S.H., Rasmussen, W., 1992, Upper Cretaceous - Lower Tertiary decapod crustaceans from West Greenland: Grønlands Geologiske Undersøgelse, Bulletin, 162, 1-46.

Collins, J.S.H., Higgs, R., Cortitula, B., 1994, A new crab, Costacopluma bifida (Crustacea, Decapoda) from the Paleocene of Venezuela: Bulletin of the Mizunami Fossil Museum, 21, 29-34.

Dibblee, T.W., Jr., 1967, Areal geology of the western Mojave Desert, California: United States Geological Survey, Professional Paper $522,1-153$

Dibblee, T.W., Jr., 1992, Geologic Map of the Topanga and Canoga Park (South 1/2) Quadrangles: Dibblee Geological Foundation Map DF-35, scale 1:24,000.

Feldmann, R.M., Martins-Neto, R.G., 1995, Costacopluma nordestiana $\mathrm{n}$. sp. (Decapoda: Retroplumidae) from the Maria Farinha Formation (Paleocene) of Brazil: Journal of Paleontology, 69, 610-611.

Feldmann, R.M., Portell, R.W., 2007, First report of Costacopluma Collins and Morris, 1975 (Decapoda: Brachyura: Retroplumidae) from the Eocene of Alabama, U.S.A.: Journal of Crustacean Biology, 27, 90-96.

Feldmann, R.M., Schweitzer, C.E., 2006, Paleobiogeography of Southern Hemisphere decapod Crustacea: Journal of Paleontology, 80(1), 83-103.

Feldmann, R.M., Casadío, S., Chirino-Gálvez, L., Aguirre-Urreta, M., 1995, Fossil decapod crustaceans from the Jaguel and Roca formations (Maastrichtian-Danian) of the Neuquén basin, Argentina: Journal of Paleontology, 69, Supplement 5(II), 1-22.

Feldmann, R.M., Rodríguez, M.F., Marínez, G.A., Aguirre-Urreta, M., 1997, Costacopluma salamanca new species (Decapoda, Retroplumidae) from the Salamanca Formation (Danian) of Patagonia, Argentina: Journal of Paleontology, 71, 125-130.

Filewicz, M.V., Hill, M.E., III, 1983, Calcareous nannofossil biostratigraphy of the Santa Susana and Llajas formations, north side Simi Valley, in Squires, R.L., Filewicz, M.V. (eds.), Cenozoic Geology of the Simi Valley Area, Southern California: Pacific Section Society of Economic Paleontologists and Mineralogists, Los Angeles, California, 45-60.

Fraaije, R.H.B., Vega, F.J., van Bakel, B.W.M., Garibay-Romero, L.M., 2006, Late Cretaceous dwarf decapods from Guerrero, southern Mexico and their migration patterns: Contributions to Zoology, 75 (3-4), 121-132.

Frederickson, N.O., 1983, Late Paleocene and early Eocene sporomorphs and thermal alteration of organic matter in the Santa Susana Formation, southern California, in Squires, R.L., Filewicz, M.V. (eds.), Cenozoic Geology of the Simi Valley Area, Southern
California: Pacific Section Society of Economic Paleontologists and Mineralogists, Los Angeles, California, 23-31.

Gaetani, M., Nicora, A., Permoli-Silva, I., Fois, E., Garzanti, E., Tintori, A., 1983, Upper Cretaceous and Paleocene in Zanskar Range (NW Himalaya): Rivista Italiana di Paleontologia i Stratigrafia, 89, 81-118.

Gardner, J.A., Bowles, E., 1934, Early Tertiary species of gastropods from the Isthmus of Tehuantepec: Journal of the Washington Academy of Sciences, 24(6), 241-248.

Gill, T., 1894, A new bassalian type of crabs: American Naturalist, 28, 1043-1045.

Gorodiski, A., Rémy, J.M., 1959, Sur les Dècapodes éocenes du Sénégal occidental: Bulletin de la Societé géologique de France, 7th Series, 1, 315-319.

Guinot, D., 1977, Propositions pour une nouvelle classification des Crustacés Décapodes Brachyoures: Compte Rendu Acádemie des Sciences Paris, série D, 285, 1049-1052.

Heitman, H.L., 1983, Paleoecological analysis and biostratigraphy of the lower Paleogene Santa Susana Formation, northern Simi Valley, Ventura County, California, in Squires, R.L., and Filewicz, M.V. (eds.), Cenozoic Geology of the Simi Valley Area, Southern California: Pacific Section Society of Economic Paleontologists and Mineralogists, Los Angeles, California, 33-44.

Kirby, M.X., 1991, Macropaleontology and biostratigraphy across the Cretaceous/Tertiary boundary, San Francisquito Formation, Warm Springs Mountain, Los Angeles County, southern California: California State University, Northridge, Unpublished M.S. thesis, $134 \mathrm{p}$.

Kirby, M.X., Saul, L.R., 1995, The Tethyan bivalve Roudairia from the Upper Cretaceous of California: Palaeontology, 38, 23-38.

Kooser, M.A., 1980, Stratigraphy and sedimentology of the San Francisquito Formation, Transverse Ranges, California: University of California, Riverside, Unpublished Ph.D. dissertation.

Kooser, M.A., 1982, Stratigraphy and sedimentology of the type San Francisquito Formation, southern California, in Crowell, J.C., Link, M.H. (eds.), Geologic history of Ridge Basin, southern California Society of Economic Paleontologists and Mineralogists, Pacific Section, 1982: Annual Convention, Anaheim, 53-62.

Latreille, P.A., 1802-1803, Histoire naturelle, general et particulière des crustacés et des insectes, 3, F. Dufart, 468 p.

Maldonado-Koerdell, M., 1950, Los estudios paleobotánicos en México con un catálogo de sus plantas fósiles: Universidad Nacional Autónoma de México, Instituto de Geología, Boletín, 55, 1-72.

McLay, C.L., 2006, Retroplumidae (Crustacea, Decapoda) from the IndoMalayan archipelago (Indonesia, Philippine) and the Melanesian arc islands (Solomon Islands, Fiji and New Caledonia), and paleogeographical comments, in Richer de Forges, B., Justine, J.L. (eds), Tropical Deep-Sea Benthos, 24: Mémoires du Muséum national d'Histoire naturelle 193, 375-391.

Nyborg, T.G., Vega, F.J., Filkorn, H.F, 2003, New Late Cretaceous and early Cenozoic decapod crustaceans from California, USA: implications for the origination of taxa in the eastern North Pacific: Contributions to Zoology, 72, 165-168.

Prothero, D.R., Vacca, R.N., 2001, Magnetic stratigraphy and tectonic rotation of the upper Paleocene San Francisquito Formation, Los Angeles County, California, in Prothero, D.R. (ed.), Magnetic Stratigraphy of the Pacific Coast Cenozoic: Pacific Section, Society for Sedimentary Geology, 91, 13-26,

Rathbun, M.J., 1926, The fossil stalk-eyed Crustacea of the Pacific slope of North America: United States National Museum Bulletin, 138, 1-155.

Saint-Laurent, M. de, 1980, Sur la classification et la phylogénie des Crustacés Décapodes Brachyoures. II. Heterotremata et Thoracotremata Guinot, 1977: Comptes Rendus hebdomadaires des Séances de l'Académie des Sciences, Paris, 290, series D, 1317-1320.

Saint-Laurent, M. de, 1989, La nouvelle superfamille des Retroplumidae Gill, 1894 (Decapoda, Brachyura): systématique, affinités et évolution, in Forest, J. (ed.), Résultats des Campagnes MUSORSTOM 5: Mémoires du Muséum national d'Histoire naturelle, 144(A), 103-179. 
Saul, L.R., 1983a, Notes on Paleogene turritellas, venericardias, and molluscan stages of the Simi Valley area, California, in Squires, R.L., Filewicz, M.V. (eds.), Cenozoic Geology of the Simi Valley Area, Southern California: Pacific Section Society of Economic Paleontologists and Mineralogists, Los Angeles, California, 71-80.

Saul, L.R., 1983b, Turritella zonation across the Cretaceous-Tertiary boundary, California: University of California Publications, Geological Sciences, 125, 1-165.

Sage, O.G., Jr., 1973, Paleocene geography of southern California: University of California, Santa Barbara, Unpublished Ph.D. thesis.

Squires, R.L., 1980, A new species of brachyuran from the Paleocene of California: Journal of Paleontology, 54, 472-476.

Squires, R.L., 1997, Taxonomy and distribution of the buccinid gastropod Brachysphingus from the uppermost Cretaceous and lower Cenozoic marine strata of the Pacific slope of North America: Journal of Paleontology, 71, 847-861.

Squires, R.L., 1999, Upper Paleocene to lower Eocene ("Meganos Stage") marine megafossils in the uppermost Santa Susana Formation, Simi Valley, southern California: Natural History Museum of Los Angeles County, Contributions in Science, 479, 1-38.

Squires, R.L., Demetrion, R.A., 1992, Paleontology of the Eocene Bateque Formation, Baja California Sur, Mexico: Natural History Museum of Los Angeles County, Contributions in Science, 434, 1-55.

Squires, R.L., Kennedy, G.L., 1998, Additions to the late Paleocene molluscan fauna from the Santa Monica Mountains, Los Angeles County, southern California: Veliger, 41, 157-171.

Squires, R.L., Saul, L.R., 1998, New upper Paleocene species of the bivalve Plicatula from southern California: Journal of Paleontology, 72, 1024-1029.

Squires, R.L., Saul, L.R., 2007, Paleocene pareorine turritellid gastropods from the Pacific slope of North America: Nautilus, 121, 1-16.

Vega, F.J., Feldmann, R.M., 1992, Occurrence of Costacopluma (Decapoda: Brachyura: Retroplumidae) in the Maastrichtian of southern Mexico and its paleobiogeographic implications: Annals of Carnegie Museum, 61(2), 133-152.
Vega, F.J., Perrilliat, M.C., 1989, Una especie nueva del género Costacopluma (Arthropoda: Decapoda) del Maastrichtiano de Nuevo León, México: Universidad Nacional Autónoma, Instituto de Geología, Revista, 8(1), 84-87.

Vega, F.J., Feldmann, R.M., Sour-Tovar, F., 1995, Fossil crabs (Crustacea: Decapoda) from the Late Cretaceous Cárdenas Formation, EastCentral Mexico: Journal of Paleontology, 69(2), 340-350.

Vega, F.J., Nyborg, T.G., Fraaije, R.H.B., Espinosa, B., 2007, Paleocene decapod Crustacea from the Rancho Nuevo Formation (Parras BasinDifunta Group), northeastern Mexico: Journal of Paleontology, 81, 1442-1451.

Vega, F.J., Nyborg , T., Coutiño, M.A., Hernández-Monzón, O., 2008, Review and additions to the Eocene decapod Crustacea from Chiapas, Mexico: Bulletin of the Mizunami Fossil Museum, 34, 51-71.

Zinsmeister, W.J., 1983a, Late Paleocene ("Martinez provincial Stage") molluscan fauna from the Simi Hills, Ventura County, California, in Squires, R.L., Filewicz, M.V. (eds.), Cenozoic Geology of the Simi Valley Area, Southern California: Pacific Section Society of Economic Paleontologists and Mineralogists, Los Angeles, California, 61-70.

Zinsmeister, W.J., 1983b., New late Paleocene molluscs from the Simi Hills, Ventura County, California: Journal of Paleontology, 57, 1282-1303.

Manuscript received: February 27, 2009.

Corrected manuscript received: August 22, 2009.

Manuscript accepted: August 27, 2009. 